\title{
Extracell Newly Ident RAGE Bind Protein Measurement
}

National Cancer Institute

\section{Source}

National Cancer Institute. Extracell Newly Ident RAGE Bind Protein Measurement. NCI

Thesaurus. Code C82011.

The determination of the amount of extracellular newly identified RAGE (receptor for advanced glycation end products) present in a sample. 